\title{
PERHITUNGAN IDLE CAPACITY DENGAN MENGGUNAKAN CAM-I CAPACITY MODEL (STUDI KASUS PADA BDK BALIKPAPAN)
}

Nurhuda ${ }^{a}$, Hendy Pernando ${ }^{b}$

aPusdiklat Pengembangan SDM, BPPK, Kementerian Keuangan, Email: nurhudamu@gmail.com bPusdiklat Pengembangan SDM, BPPK, Kementerian Keuangan, Email: pernandoh@gmail.com

\section{INFO ARTIKEL}

SEJARAH ARTIKEL

Diterima Pertama

14 Januari 2020

Dinyatakan Dapat Dimuat 11 Desember 2020

KATA KUNCI:

CAM-I Capacity Model, Idle capacity BMN.

\begin{abstract}
ABSTRAK
Implementasi Kementerian Keuangan Corporate University meningkatkan persentase pembelajaran digital melalui e-learning, tetapi berpotensi mengurangi penggunaan aset fisik. Fenomena idle capacity pada BMN di satuan kerja BPPK perlu dihitung sebagai dasar dalam penentuan kebijakan pengelolaan aset. Lingkup penelitian dibatasi pada Balai Diklat Keuangan (BDK) Balikpapan. Penelitian kualitatif ini menggunakan CAM-I Capacity Model yang dapat menentukan tingkat idle capacity aset suatu entitas. Data yang digunakan adalah data primer berupa data penggunaan BMN tahun 2017 s.d. 2019. Hasil penelitian menunjukkan bahwa productive capacity asrama BDK Balikpapan dari tahun 2017-2019 lebih rendah dibandingkan idle capacity, baik secara tahunan maupun secara rerata dalam rentang waktu tersebut. Selain itu, penelitian ini memberikan rekomendasi alternatif kebijakan pengelolaan idle capacity tersebut. Data terkait tingkat idle capacity diperlukan dalam penentuan kebijakan pengelolaan aset. CAM-I Capacity Model dapat dikembangkan untuk menghitung idle capacity BMN dan bangunan yang berhubungan langsung dengan penyelenggaraan pelatihan.
\end{abstract}

Implementation of Corporate University increase digital learning allotment in Ministry of Finance via e-learning, although subsequently reduce physical assets utilization. Idle capacity phenomena on state-owned assets in FETA (Finance Education and Training Agency) unit workforce needs to be calculated as a base on assets management policy making. Employing CAM-I Capacity Model, this research aims to determine assets idle capacity rate on entity. Using primary data such state-owned assets utilization from 2017 to 2019. This research shows that state-owned assets idle capacity rate for Balikpapan Financial Education and Training Hall Center (BDK Balikpapan) from 2017 to 2019 is higher than its productive capacity rate. Furthermore, this research proposes alternative policy in managing idle capacity. Asset management policy making needs idle capacity data. CAM-I Capacity Model could be developed to calculate state-owned assets and building idle capacity directly related to training arrangement.

\section{PENDAHULUAN}

\subsection{Latar Belakang}

Disrupsi dapat mengubah bagaimana cara organisasi bekerja. Cara dan metode sebelumnya yang dianggap berhasil, menjadi sesuatu yang konvensional dan perlu diperbaiki, atau dalam kasus yang lebih ekstrem, menjadi tidak relevan lagi. E-learning yang diadopsi dengan cepat oleh Badan Pendidikan dan Pelatihan Keuangan (BPPK) memberi tantangan baru dalam pengelolaan pelatihan dan berbagai infrastruktur penunjangnya, termasuk Barang Milik Negara (BMN) yang dikelola dan digunakan selama ini untuk kegiatan operasional "konvensional" BPPK.
Undang-undang Nomor 17 Tahun 2003 tentang Keuangan Negara mendefinisikan keuangan negara sebagai semua hak dan kewajiban negara yang dapat dinilai dengan uang, serta segala sesuatu baik berupa uang maupun berupa barang yang dapat dijadikan milik negara berhubung dengan pelaksanaan hak dan kewajiban tersebut. Pasal 9 undang-undang tersebut mengatur bahwa salah satu tugas Menteri/pimpinan lembaga adalah melaksanakan anggaran kementerian negara /lembaga yang dipimpinnya dan mengelola barang milik/kekayaan negara yang menjadi tanggung jawab kementerian negara/lembaga yang dipimpinnya. Dalam pengelolaan keuangan, pengelolaan BMN harus beriringan dengan pengelolaan anggaran. Berdasarkan Tabel 1, 
perbandingan aset negara, terutama aset tetap terhadap nilai APBN berada di atas $85 \%$. Pada tahun 2015-2017, nilai aset tetap bahkan melebihi nilai APBN tahun tersebut.

Tabel 1 Perbandingan nilai APBN dengan Aset pada Neraca (dalam Miliar Rupiah)

\begin{tabular}{|c|c|c|c|}
\hline Tahun & APBN & Aset pada Neraca & $\begin{array}{c}\text { Perbandingan Aset Tetap } \\
\text { pada APBN }\end{array}$ \\
\hline 2014 & $1.777,18$ & $1.714,59$ & $96,48 \%$ \\
\hline 2015 & $1.806,51$ & $1.852,04$ & $102,52 \%$ \\
\hline 2016 & $1.864,27$ & $1.921,79$ & $103,09 \%$ \\
\hline 2017 & $2.007,35$ & $2.034,80$ & $101,37 \%$ \\
\hline 2018 & $2.213,11$ & $1.931,05$ & $87,26 \%$ \\
\hline
\end{tabular}

Sumber: LKPP (Audited) 2015-2018, Kemenkeu

Badan Pemeriksa Keuangan menyebutkan permasalahan pengelolaan aset perlu mendapatkan perhatian pemerintah salah satunya adalah pengelolaan barang milik negara yang tidak digunakan (idle). Tabel 2 menunjukkan bahwa dari tahun 2015-2018 terdapat peningkatan BMN idle sebesar $161 \%$, dengan pertambahan tiap tahunnya sebesar $84,80 \% \quad$ (2016), 34,56\% (2017), 45,22\% (2018). Nilai tersebut menjadi lebih besar jika tidak hanya menghitung BMN idle, melainkan juga idle capacity dari setiap BMN.

Tabel 2 BMN idle tahun 2014-2018

\begin{tabular}{|c|c|c|}
\hline Tahun & BMN Idle & \% Pertambahan BMN Idle \\
\hline 2014 & 30.147 .664 .105 & \\
\hline 2015 & 21.983 .187 .943 & $-27,08 \%$ \\
\hline 2016 & 40.623 .835 .279 & $84,80 \%$ \\
\hline 2017 & 54.663 .708 .402 & $34,56 \%$ \\
\hline 2018 & 79.383 .729 .148 & $45,22 \%$ \\
\hline
\end{tabular}

Sumber: LKPP (Audited) 2015-2018, Kemenkeu

Dalam lingkup yang lebih kecil, BDK Balikpapan selaku Unit Akuntansi Kuasa Pengguna Barang (UAKPB) mengelola BMN dengan nilai yang meningkat tiap tahunnya. Data pada Tabel 3 menunjukkan bahwa dari tahun 2010-2019 terjadi kenaikan nilai BMN lebih dari 100\%. Jika merujuk pada Peraturan Menteri Keuangan Nomor 71/PMK.06/2016, pada BDK Balikpapan tidak terdapat aset yang tergolong idle. Namun, terdapat potensi idle capacity pengelolaan BMN karena kapasitas penggunaan BMN yang tidak optimal. Padahal, pengelolaan yang lebih optimal dapat memberikan manfaat berupa penerimaan PNBP.

Tabel 3 BMN BDK Balikpapan tahun 2014-2018

\begin{tabular}{|c|c|c|c|}
\hline Tahun & Nilai BMN & Tahun & Nilai BMN \\
\hline 2010 & 30.477 .503 .248 & 2015 & 37.112 .866 .797 \\
\hline 2011 & 32.020 .325 .704 & 2016 & Tidak terdapat data \\
\hline 2012 & 32.992 .183 .423 & 2017 & 61.671 .826 .885 \\
\hline 2013 & 34.474 .379 .747 & 2018 & 61.374 .057 .960 \\
\hline 2014 & 34.979 .653 .966 & 2019 & 61.173 .646 .523 \\
\hline
\end{tabular}

Sumber: BPPK (2016)

BPPK sejak tahun 2015 telah menetapkan Corporate University sebagai srategic tool untuk mencapai tujuan organisasi. Dalam KEP-140/PP/2017 tentang cetak biru Kemenkeu Corporate University, $e$ learning menjadi salah satu fokus dari Kemenkeu
Corporate University. Hal tersebut diperkuat dalam inisiatif strategis Kementerian Keuangan 2019-2021 yaitu e-learning modern sebagai alat utama dalam pengembangan SDM. Dalam milestones inisiatif strategis tersebut, BPPK menargetkan implementasi pembelajaran e-learning mencapai 30\% dari total pembelajaran pada tahun 2019. Target tersebut meningkat menjadi $50 \%$ pada tahun 2020 dan $70 \%$ pada tahun 2021. Pada praktiknya, hal tersebut ditetapkan menjadi salah satu Indikator Kinerja Utama (IKU) BPPK, yaitu persentase penyelenggaraan pembelajaran digital. IKU tersebut diturunkan hingga Pusdiklat.

Sebagai unit vertikal dari BPPK, kegiatan pembelajaran di BDK Balikpapan dipengaruhi oleh kebijakan di tingkat pusat. Berdasarkan notula rapat koordinasi BPPK tahun 2018, belum ada kebijakan definitif terkait penyelarasan penyelenggaraan pelatihan antara Pusdiklat dengan BDK, baik untuk pelatihan klasikal maupun e-learning. Namun, Tabel 4 menunjukkan bahwa dari tahun 2017-2020 terjadi penurunan alokasi penyelenggaraan pelatihan tatap muka di BDK Balikpapan. Penurunan proporsi pelatihan tatap muka seiring dengan meningkatnya proporsi pelatihan e-learning berpotensi meningkatkan idle capacity BMN di BDK Balikpapan. Atas pertimbangan tersebut, penulis menilai pentingnya perhitungan idle capacity untuk mengetahui pengaruh kebijakan implementasi pembelajaran e-learning di BDK Balikpapan. Selain itu, perhitungan idle capacity dapat digunakan dalam pengambilan keputusan. Hal tersebut diperkuat dengan kondisi tidak terdapat mekanisme perhitungan idle capacity di unit pemerintahan. Penulis menggunakan best practice penghitungan idle capacity di organisasi privat, dengan menggunakan CAM-I Capacity Model.

Tabel 4 Penyelenggaraan Pembelajaran di BDK Balikpapan tahun 2014-2020

\begin{tabular}{|c|c|}
\hline Tahun & Jumlah Pelatihan Tatap Muka \\
\hline 2014 & 30 Pelatihan \\
\hline 2015 & 49 Pelatihan \\
\hline 2016 & 26 Pelatihan \\
\hline 2017 & 32 Pelatihan \\
\hline 2018 & 30 Pelatihan \\
\hline 2019 & 24 Pelatihan \\
\hline 2020 & 18 Pelatihan* \\
\hline
\end{tabular}

*Rencana Kalender Pembelajaran

Sumber: Data Semantik, BPPK

\subsection{Rumusan Masalah}

Penelitian ini diharapkan dapat menjawab pertanyaan tentang bagaimana kondisi idle capacity penggunaan asrama BDK Balikpapan selama tahun 2017-2019.

\subsection{Tujuan Penelitian}


Tujuan dari penelitian ini adalah untuk mendapatkan data idle capacity pengelolaan asrama BDK Balikappan yang dapat digunakan sebagai dasar dalam pengambilan keputusan terkait pengelolaan aset.

\subsection{Keaslian Penelitian}

Berdasarkan hasil pengamatan dan penelusuran kepustakaan yang dilakukan, belum terdapat penelitian terkait penggunaan CAM-I Capacity Model pada sektor publik, sehingga keaslian penelitian ini dapat dipertanggungjawabkan.

\section{KERANGKA TEORITIS DAN PENGEMBANGAN HIPOTESIS}

\subsection{Kemenkeu Corporate University}

BPPK memiliki tanggung jawab dalam pengembangan SDM pengelola keuangan dan kekayaan negara melalui penyelenggaraan pendidikan dan pelatihan. Untuk melaksanakan peran tersebut, BPPK telah menyusun rencana strategis tahun 20152019 yang meliputi rumusan visi, misi, serta arah kebijakan. Salah satu misi BPPK adalah membangun sistem pendidikan dan pelatihan SDM yang terintegrasi dalam mewujudkan corporate university. Corporate university adalah strategi Kementerian Keuangan dalam mencapai visinya dengan mewujudkan link and match antara pembelajaran, pengelolaan pengetahuan, dan penerapan nilai-nilai dengan target kinerja.

Corporate university berfokus pada strategic organization dan business performance yang akan menerapkan model 70-20-10 learning and development dari Michael Lombardo dan Eichinger (2010). Gambar 1 menunjukkan proses penyusunan pembelajaran untuk mencapai visi, misi, dan sasaran kinerja Kementerian Keuangan. Proses dimulai dengan identifikasi kebutuhan pembelajaran yang berfungsi untuk memperkuat performa individu dan organisasi. Pembelajaran kembangkan dengan penguatan budaya belajar dan pemanfaatan knowledge management. Metode pembelajaran yang diterapkan tidak hanya difokuskan pada pembelajaran klasikal, tetapi juga melalui coaching, mentoring, feedback, community of practice, project and assignment, action learning, problem solving, on the job training, internship, rotasi, task force, dan pembelajaran e-learning.

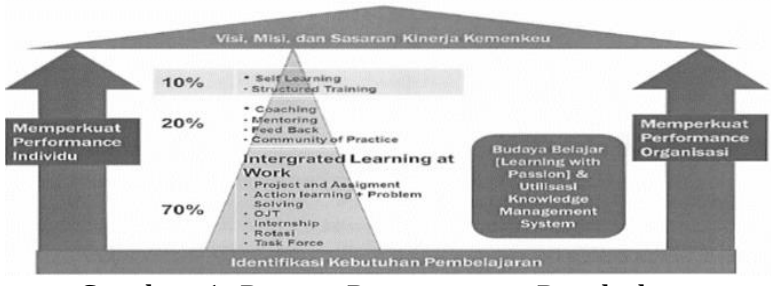

Gambar 1: Proses Penyusunan Pembelajaran Sumber: KEP-140/PP/2017

\subsection{Pengelolaan BMN}

BMN adalah semua barang yang dibeli atau diperoleh atas beban Anggaran Pendapatan dan Belanja Negara (APBN) atau berasal dari perolehan lainnya yang sah. BMN berupa tanah dan bangunan memiliki peran yang strategis dalam penyelenggaraan tugas dan fungsi pemerintahan. BMN perlu dikelola secara tepat, efektif, dan optimal untuk penyelenggaraan pemerintahan yang efektif dan efisien. Pengelolaan BMN didasarkan pada Peraturan Pemerintah (PP) Nomor 27 Tahun 2014 yang telah diubah dengan PP Nomor 28 Tahun 2020 tentang Pengelolaan Barang Milik Negara/Daerah (BMN/D). Menurut ketentuan tersebut, pengelolaan BMN dilakukan dengan mengadopsi siklus pengelolaan aset tetap, yakni perencanaan kebutuhan dan penganggaran, pengadaan, penggunaan, pemanfaatan, pengamanan dan pemeliharaan, penilaian, penghapusan, pemindahtanganan, penatausahaan, serta pembinaan, pengawasan, dan pengendalian.

Pengadaan BMN dimaksudkan untuk digunakan dalam penyelenggaraan tugas dan fungsi pengguna barang/kuasa pengguna secara optimal. Di sisi lain, terdapat aset berupa tanah dan bangunan yang tidak digunakan (idle). Menurut Jusmin (2013) salah satu penyebab aset idle adalah ketidaktertiban dalam pengelolaan data barang atau aset. Pengelolaan BMN idle berpedoman pada Peraturan Menteri Keuangan Nomor 250/PMK.06/2011 tentang Tata Cara Pengelolaan BMN yang Tidak Digunakan untuk Menyelenggarakan Tugas dan Fungsi Kementerian/Lembaga (K/L). BMN idle adalah BMN berupa tanah dan/atau bangunan yang tidak digunakan untuk kepentingan penyelenggaraan tugas dan fungsi K/L. Adapun kriteria BMN idle meliputi:

1) BMN yang sedang tidak digunakan dalam penyelenggaraan tugas dan fungsi $\mathrm{K} / \mathrm{L}$, atau

2) BMN yang digunakan tetapi tidak sesuai dengan tugas dan fungsi K/L.

Pengertian kapasitas menurut McNair (1994) dalam Irwanti (2011) adalah sumber daya yang dimiliki oleh perusahaan yang siap untuk digunakan yang menggambarkan potensi manfaat yang akan didapatkan oleh perusahaan pada masa mendatang. Mengutip Institute of Management Accountants (1996), theoretical capacity adalah optimal amount of work that a process or plant can complete using a 24hours, seven-day operation with zero waste. Theoretical capacity setara dengan 100\% kapasitas total. Praktiknya, aset tidak sepenuhnya digunakan untuk tujuan produktif, sehingga akan selalu ada kapasitas yang digunakan untuk keperluan nonproductive ataupun idle. Sopariwala (2016) berpendapat bahwa capacity underutilization adalah hal normal dalam setiap lingkungan bisnis. Menurut Huefner (2016) terdapat berbagai alasan suatu aset memiliki kapasitas yang idle. Aditya (2014) berpendapat bahwa manajemen kapasitas dewasa ini menjadi hal yang penting baik dalam jangka pendek maupun jangka panjang. Identifikasi penyebab idle capacity memampukan manajemen untuk mengambil 
keputusan strategis investasi yang tepat sehingga dapat terhindar dari kesalahan perolehan tambahan sumber daya, dan akhirnya dapat dijadikan dasar untuk memperbaiki idle capacity tersebut.

\subsection{CAM-I Capacity Model}

Setidaknya terdapat 12 model yang dapat digunakan dalam menentukan idle capacity suatu sumber daya. Namun, tidak terdapat model penghitungan yang dapat diterapkan pada semua kasus. "There is no one, universally correct model, measure or approach to capacity management and measurement in complex, modern organization" menurut Institute of Management Accountant (1996). CAM-I Capacity Model digunakan dalam tulisan ini karena fokusnya dalam mengomunikasikan dan memberikan rekomendasi dalam pengelolaan idle capacity. Keunggulan CAM-I Capacity Model adalah dapat digunakan dalam proses perencanaan maupun kendali. Dengan mempertimbangkan sedikitnya data penggunaan BMN yang ada, CAM-I Capacity Model menjadi model perhitungan idle capacity paling tepat karena menggunakan theoretical capacity bukan practical capacity.

Capacity didefinisikan sebagai Capacity model merupakan suatu metodologi manajemen biaya kapasitas yang menekankan terhadap perbaikan utilitas kapasitas yang dimiliki entitas. Menurut Aditya (2014), konsep capacity model berfokus untuk mengidentifikasi variabilitas dan pemborosan kapasitas organisasi. Dalam CAM-I Capacity Model, kapasitas aset dibagi dalam beberapa kapasitas spesifik sebagaimana pada Gambar 2 .

CAM-I Capacity Model pada awalnya digunakan untuk mengukur kapasitas produksi pada industri manufaktur, Namun demikian, Preda (2003) menjelaskan bahwa isu capacity management pada industri manufaktur paralel dengan isu pada manajemen gedung dan bangunan, dengan contoh pada pengelolaan gedung olahraga. Menurut Peda (2003) terdapat dua perbedaan utama, yaitu tidak terjadi produksi dan tidak terdapat inventory. Perbedaan tersebut bukan merupakan kendala dalam penggunaan CAM-I Capacity Model untuk meningkatkan efisiensi pengelolaan aset.

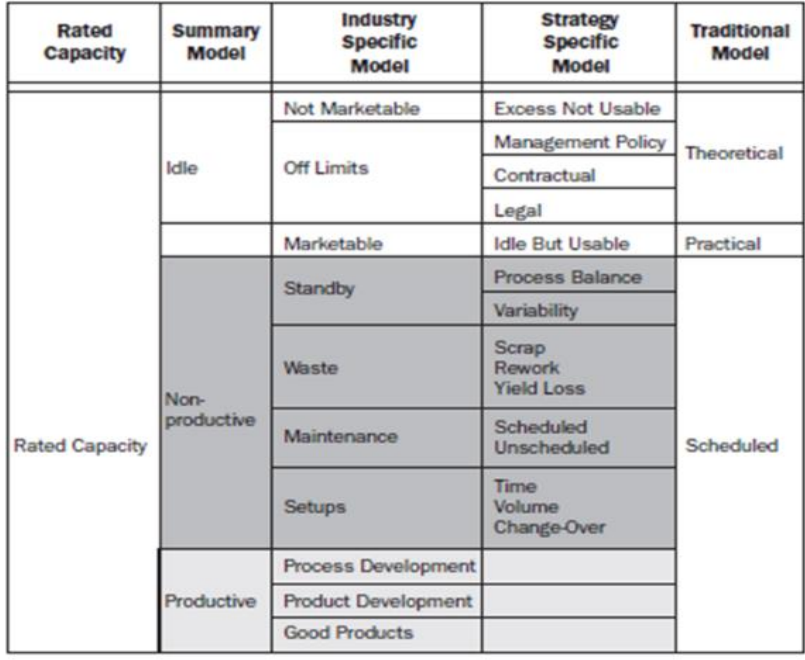

Gambar 2: CAM-I Capacity Model Sumber: Institute of Management Accounting

\subsection{Pengembangan Hipotesis}

Strategi corporate university menerapkan $e$ learning sebagai salah satu bentuk pembelajaran. Dalam sudut pandang pengelolaan BMN, e-learning dapat berdampak pada peningkatan idle capacity BMN, sehingga perlu dilakukan perhitungan idle capacity menggunakan CAM-I capacity model.

\section{METODOLOGI PENELITIAN}

Pendekatan yang digunakan dalam penelitian ini adalah pendekatan kualitatif dengan menggunakan metode CAM-I Capacity Model dalam menentukan nilai dari permasalahan yang diteliti. Berdasarkan model tersebut, kapasitas dibagi menjadi 4, sebagai berikut:

a. Rated capacity

Merupakan kapasitas total, yang dihitung dengan mengalikan kapasitas harian dengan jumlah hari.

b. Productive capacity

Dihitung dari penggunaan asrama untuk penyelenggaraan pelatihan, maupun penggunaan asrama oleh pihak lain.

c. Nonproductive capacity

Dihitung dengan menjumlahkan hari yang diklasifikasikan sebagai standby, waste, setups, dan maintenance.

d. Idle capacity

Dihitung dengan mengurangkan productive capacity dan nonproductive capacity dari rated capacity.

Data yang digunakan dalam penelitian ini adalah data primer yang didapatkan dari dokumen dan melalui proses wawancara. Data kuantitatif pengelolaan BMN pada BDK Balikpapan dibandingkan dengan kapasitas total BMN untuk menentukan tingkat idle capacity. Dalam proses pengelolaan tertentu, diperlukan professional judgement yang didasarkan pada hasil wawancara pihak manajerial dan pegawai BDK Balikpapan serta narasumber lainnya. Wawancara dilakukan terhadap empat orang, yaitu Kasubbag Tata Usaha dan Kepatuhan Internal 
(TUKI) dan tiga pramugraha. Kasubbag TUKI merupakan pejabat yang berwewenang dan bertanggung jawab dalam pengelolaan BMN di BDK Balikpapan. Pramugraha BDK Balikpapan adalah Pegawai Pemerintah Non Pegawai Negeri (PPNPN) yang bertugas melakukan secara langsung menyiapkan dan membersihkan asrama BDK Balikpapan.

\section{HASIL DAN PEMBAHASAN}

Dengan CAM-I Capacity Model, kapasitas BMN BDK Balikpapan dikelompokkan menjadi rated capacity, productive capacity, nonproductive capacity, dan idle capacity. Fokus tulisan ini adalah menghitung idle capacity dan rated idle capacity dari BMN BDK Balikpapan.

BPPK memiliki room management system (RMS) yang dapat mendata penggunaan BMN. Namun, setelah proses pengumpulan data, diketahui bahwa RMS belum diimplementasikan dengan tertib, sehingga data yang memadai tentang penggunaan ruang kelas belum tersedia, sedangkan penggunaan asrama dapat dilihat dengan menggunakan data pelaksanaan pelatihan. Oleh karena itu, pembahasan idle capacity pada BDK Balikpapan akan difokuskan pada penggunaan asrama.

\subsection{Rated capacity}

Rated capacity adalah perkiraan total kapasitas output suatu aset. Secara umum, rated capacity didasarkan pada asumsi bahwa aset tersebut dapat digunakan secara terus-menerus selama 24 jam dalam satu tahun penuh, sehingga perhitungannya adalah 24 jam $\times 365$ hari $=8.760$ jam. Berdasarkan hasil wawancara, penggunaan asrama BDK Balikpapan menggunakan satuan hari sehingga rated capacity asrama yang dimiliki BDK Balikpapan untuk tahun 2017, 2018, dan 2019 adalah 365 hari untuk setiap kamar asrama BDK Balikpapan, sehingga total rated capacity asrama BDK Balikpapan adalah rated capacity tersebut dikalikan dengan jumlah unit kamar yang dimiliki (33 unit) seperti ditunjukkan pada Tabel 5.

Tabel 5 Rated capacity Asrama BDK Balikpapan

\begin{tabular}{|l|l|l|}
\hline No & Tahun & Rated Capacity \\
\hline 1 & 2017 & 12045 kamar setahun \\
\hline 2 & 2018 & 12045 kamar setahun \\
\hline 3 & 2019 & 12045 kamar setahun \\
\hline
\end{tabular}

Sumber: data diolah oleh penulis (2019)

Kapasitas asrama tersebut dikonfirmasi melalui wawancara dan pengamatan. Berdasarkan analisis, dapat diketahui kapasitas per tahun. Kapasitas ini merupakan theoretical capacity, karena secara teori kamar asrama BDK Balikpapan dapat digunakan sepanjang waktu, tidak terpengaruh dengan hari Sabtu/Minggu serta hari libur. Hal ini dibuktikan dengan penggunaan asrama di hari Minggu dan Sabtu ketika terdapat pelaksanaan pelatihan. Theoretical capacity penggunaan ruang kelas dan aula juga dapat dihitung, tetapi karena tidak terdapat data penggunaan, pembagian kapasitas tidak dapat ditentukan pada tahapan berikutnya.

\subsection{Productive capacity}

Productive capacity adalah kapasitas optimal yang digunakan dalam kegiatan atau proses produksi suatu produk atau jasa. Tugas dan fungsi BDK Balikpapan adalah penyelenggaraan pelatihan. Pasal 3 Peraturan Menteri Keuangan Nomor 246/PMK.06/2014 mengatur bahwa penggunaan BMN dibatasi untuk penyelenggaraan tugas dan fungsi entitas tersebut. Atas dasar itu, productive capacity adalah penggunaan BMN untuk penyelenggaraan pelatihan. Data penggunaan asrama untuk menunjang pelatihan didapat dari kalender diklat/pelatihan BDK Balikpapan tahun 2017, 2018, dan 2019.

Berdasarkan wawancara, penggunaan asrama untuk penyelenggaraan pelatihan dimulai $\mathrm{H}-1$ pelatihan, saat pelatihan, sampai $\mathrm{H}+1$ pelatihan, sehingga productive capacity asrama dihitung dengan menjumlahkan penggunaan kamar untuk setiap pelatihan dari $\mathrm{H}-1$ hingga $\mathrm{H}+1$. Dalam kalender pelatihan tidak terdapat data pasti jumlah kamar yang digunakan, sehingga peneliti memperhitungkan penggunaan kamar dengan membandingkan realisasi jumlah peserta. Perhitungan tersebut memperhatikan jumlah peserta perempuan dan peserta laki-laki, misalnya pada penyelenggaraan DTSS Petugas Tempat Pelayanan Terpadu tahun 2017 dengan peserta 28 orang, yang terdiri dari 19 orang laki-laki dan 9 orang perempuan. Diperkirakan penggunaan kamar sebanyak 10 kamar untuk laki-laki dan 5 kamar untuk perempuan. Secara teori, 28 peserta dapat tertampung dalam 14 kamar dengan kapasitas 2 orang. Namun, dalam praktiknya, peserta perempuan dan peserta laki-laki tidak ditempatkan pada kamar yang sama. Sebagai catatan, idle capacity berupa kamar asrama yang tidak terisi penuh tidak termasuk dalam perhitungan pada tulisan ini. Hasil perhitungan productive capacity asrama BDK Balikpapan tahun 2017, 2018, dan 2019 ditunjukkan pada Tabel 6.

Tabel 6 Productive capacity Asrama BDK Balikpapan

\begin{tabular}{|l|l|l|}
\hline No & Tahun & Productive Capacity \\
\hline 1 & 2017 & 3822 kamar setahun \\
\hline 2 & 2018 & 5530 kamar setahun \\
\hline 3 & 2019 & 4903 kamar setahun \\
\hline
\end{tabular}

Sumber: data diolah oleh penulis (2019)

BMN yang tidak digunakan atau tidak sedang digunakan dalam penyelenggaraan tugas dan fungsinya, sesuai dengan Pasal 18 PMK 87/PMK.06/2016, dapat diusulkan untuk dioperasikan pihak lain, sepanjang dalam rangka menjalankan pelayanan umum sesuai tugas dan fungsi $\mathrm{K} / \mathrm{L}$.

Selain penyelenggaraan pelatihan, asrama BDK Balikpapan digunakan juga oleh instansi lain dalam 
rangka tugas dan fungsinya. Data penggunaan tersebut didapat dari surat/nota dinas yang diterima oleh BDK Balikpapan terkait peminjaman asrama. Sama dengan penggunaan untuk penyelenggaraan pelatihan, dalam hal peminjaman oleh instansi lain, asrama dapat digunakan sejak $\mathrm{H}-1$ hingga $\mathrm{H}+1$ kegiatan. Data peminjaman asrama BDK Balikpapan tahun 2017, 2018, dan 2019 berdasarkan surat/nota dinas peminjaman sebagaimana Tabel 7.

Tabel 7 Peminjaman Asrama BDK Balikpapan

\begin{tabular}{|l|l|l|}
\hline No & Tahun & Kapasitas yang digunakan \\
\hline 1 & 2017 & 177 kamar setahun \\
\hline 2 & 2018 & 0 kamar setahun \\
\hline 3 & 2019 & 120 kamar setahun \\
\hline
\end{tabular}

Sumber: data diolah oleh penulis (2019)

Asrama BDK Balikpapan juga digunakan pihak lain yang dikenakan tarif sewa karena tidak memenuhi aturan Pasal 18 PMK 87/PMK.06/2016. Praktik tersebut diatur dalam pasal 5 PMK Nomor 57/PMK.06/2016 tentang Tata Cara Pelaksanaan Sewa Barang Milik Negara yang mengurai besaran sewa yang menjadi penerimaan negara. Data diperoleh dari data PNBP penerimaan sewa kamar asrama. Data penyewaan asrama BDK Balikpapan tahun 2017, 2018, dan 2019 adalah sebagaimana Tabel 8 .

Berdasarkan PMK Nomor 246/PMK.06/2014, PMK Nomor 87/PMK.06/2016, dan PMK Nomor 57/PMK.06/2016, peneliti menyimpulkan total productive capacity asrama BDK Balikpapan adalah penggunaan dalam penyelenggaraan pelatihan, oleh instansi lain sesuai tugas dan fungsinya, serta ketika disewakan untuk PNBP. Productive capacity asrama BDK Balikpapan tahun 2017, 2018, dan 2019 adalah sebagaimana Tabel 9.

Tabel 8 Penyewaan Asrama BDK Balikpapan

\begin{tabular}{|l|l|l|}
\hline No & Tahun & Kapasitas yang digunakan \\
\hline 1 & 2017 & 177 kamar setahun \\
\hline 2 & 2018 & 0 kamar setahun \\
\hline 3 & 2019 & 120 kamar setahun \\
\hline
\end{tabular}

Sumber: data diolah oleh penulis (2019)

Tabel 9 menunjukkan productive capacity rate, yaitu hasil bagi productive capacity dengan rated capacity. Productive capacity rate tertinggi adalah pada tahun 2019. Namun, angka tersebut belum mencerminkan penggunaan asrama yang lebih optimal di tahun 2019, karena ada faktor pembagi yang berbeda. Faktor pembagi tahun 2019 lebih kecil karena rated capacity diukur sampai akhir Oktober. Pada praktiknya, di bulan November dan Desember penggunaan asrama relatif rendah karena tidak banyak kegiatan pelatihan. Data pada kalender pelatihan tahun 2019 pun menunjukkan bahwa Pelatihan Teknis Pemeriksaan Barang Ekspor yang diselenggarakan pada tanggal 7 s.d. 23 Oktober 2019 merupakan pelatihan terakhir pada tahun 2019.
Peneliti berpendapat, jika perhitungan dilakukan pada akhir tahun, productive capacity rate tahun 2019 akan lebih rendah dari 50,16\%.

Tabel 9 Productive Capacity Rate Asrama BDK Balikpapan

\begin{tabular}{|l|l|l|l|}
\hline No & \multicolumn{1}{|c|}{ Tahun } & \multicolumn{1}{c|}{$\begin{array}{c}\text { Kapasitas yang } \\
\text { digunakan }\end{array}$} & $\begin{array}{c}\text { Productive } \\
\text { Capacity Rate }\end{array}$ \\
\hline 1 & 2017 & 4053 kamar setahun & $33,65 \%$ \\
\hline 2 & 2018 & 5582 kamar setahun & $46,34 \%$ \\
\hline 3 & 2019 & 5064 kamar setahun & $42,04 \%$ \\
\hline
\end{tabular}

Sumber: data diolah oleh penulis (2019)

\subsection{Nonproductive capacity}

Nonproductive capacity adalah kapasitas yang digunakan bukan dalam proses memproduksi barang atau jasa. CAM-I Capacity Model membagi nonproductive capacity dalam kategori standby, waste, setups, dan maintenance. Nonproductive capacity perlu diminimalisasikan untuk mengurangi inefisiensi kegiatan operasional.

Waste capacity adalah kapasitas yang digunakan bukan dalam kegiatan produktif, dan juga tidak menunjang kegiatan produktif. Mengikuti penjabaran tentang productive capacity, waste capacity muncul saat BMN digunakan bukan dalam rangka penyelenggaraan pelatihan, penggunaan oleh instansi lain, maupun penyewaan. BMN yang digunakan bukan untuk pelayanan umum maupun kegiatan yang menghasilkan penerimaan negara merupakan waste. Dalam PMK 57/PMK.06/2016, waste adalah penggunaan BMN oleh pihak lain secara tidak sah. Salah satu tujuan mekanisme penyewaan BMN adalah untuk menghindari waste. BDK Balikpapan telah melaksanakan mekanisme penyewaan BMN melalui Surat Kepala BDK Balikpapan Nomor S101/BPP.9/2017 tanggal 9 Februari 2017 perihal Surat Permohonan Penilaian Nilai Wajar dalam Rangka Penentuan Tarif Pokok Sewa BMN di Lingkungan BDK Balikpapan. KPKNL Balikpapan selaku pengelola barang telah melakukan penilaian dan penetapan nilai sewa wajar asrama BDK Balikpapan. Peneliti meyakini tidak terdapat waste pada BDK Balikpapan, karena penerapan mekanisme penyewaan BMN. Sebagai contoh, pada bulan Oktober 2017 terdapat penyetoran sewa kamar asrama oleh keluarga pegawai BDK Balikpapan.

Standby capacity adalah kapasitas yang tidak digunakan karena menunggu proses lain yang tidak direncanakan sebelumnya. Pada penggunaan asrama BDK Balikpapan, standby capacity timbul ketika kamar asrama disiapkan sesuai dengan rencana jumlah peserta dengan realisasi peserta yang lebih sedikit, misalnya karena pembatalan peserta. Peneliti tidak dapat melakukan perhitungan standby capacity karena terbatasnya data. Pada kalender pelatihan terdapat data rencana peserta, tetapi apakah jumlah tersebut menjadi dasar pelaksanaan set-ups kamar tidak dapat dipastikan. Berdasarkan petimbangan 
tersebut, peneliti tidak menyertakan standby capacity dalam perhitungan nonproductive capacity ini.

Tabel 10: Set-ups Capacity Asrama BDK Balikpapan

\begin{tabular}{|l|l|l|}
\hline No & Tahun & Kapasitas yang digunakan \\
\hline 1 & 2017 & 620 kamar setahun \\
\hline 2 & 2018 & 470 kamar setahun \\
\hline 3 & 2019 & 476 kamar setahun \\
\hline
\end{tabular}

Sumber: data diolah oleh penulis (2019)

Set-ups capacity adalah kapasitas yang digunakan untuk menyiapkan BMN agar siap digunakan sebagaimana mestinya. Set-ups capacity mengacu pada data penggunaan asrama. Hasil wawancara menunjukkan bahwa diperlukan waktu satu hari untuk penyiapan penyelenggaraan satu kelas pelatihan serta satu hari untuk pembersihan setelah penyelenggaraan pelatihan. Jadi, untuk setiap pelatihan set-ups capacity yang digunakan adalah 2 hari dikalikan dengan jumlah kamar yang digunakan. Hasil perhitungan dapat dilihat pada Tabel 10.

Tabel 11 Maintenance Capacity Asrama BDK Balikpapan

\begin{tabular}{|l|l|l|}
\hline No & Tahun & Kapasitas yang digunakan \\
\hline 1 & 2017 & 585 kamar setahun \\
\hline 2 & 2018 & 462 kamar setahun \\
\hline 3 & 2019 & 252 kamar setahun \\
\hline
\end{tabular}

Sumber: data diolah oleh penulis (2019)

Maintenance capacity adalah kapasitas yang digunakan untuk perbaikan kamar agar dapat berfungsi optimal. Maintenance terdiri dari unplaned maintenance dan planned maintenance. Unplaned maintenance adalah perbaikan yang dilakukan seketika terjadi kerusakan. Umumnya, proses ini dilakukan beriringan dengan penggunaan kamar, sehingga tidak mempengaruhi kapasitas terpakai. Planned maintenance merupakan perbaikan yang direncanakan dilakukan untuk meningkatkan kualitas kamar. Planned maintenance umumnya membutuhkan waktu lebih dari satu hari sehingga mempengaruhi kapasitas kamar yang digunakan. Pada tahun 20172019 terdapat tiga perbaikan yang tergolong planned maintenance, yaitu pengadaan pekerjaan konstruksi renovasi asrama dan pembuatan tempat parkir BDK Balikpapan Tahun 2017, pengadaan peralatan pendukung asrama dan kelas BDK Balikpapan 2018, serta pekerjaan perbaikan kebocoran atap dan pemeliharaan gedung $\mathrm{F}$ tahun 2019. Peneliti melakukan perhitungan kapasitas terpakai untuk maintenance capacity dengan menggunakan data dari dokumen-dokumen pengadaan. Data yang ada adalah data kontrak pelaksanaan pekerjaan, sehingga kapasitas terpakai bersifat theoretical bukan practical. Hasil perhitungan maintenance capacity ditunjukkan Tabel 11.

Berdasarkan penjelasan tersebut, nonproductive capacity dapat dihitung dengan menjumlahkan set-ups capacity dan maintenance capacity. Hasil tersebut dibandingkan dengan rated capacity sehingga menghasilkan nonproductive capacity rate. Data ini dapat digunakan untuk mengurangi inefisiensi penggunaan BMN, seperti mengurangi set-ups time, defect, atau lainnya. Secara keseluruhan nonproductive capacity dapat dilihat pada Tabel 12 .

Tabel 12 Nonproductive capacity Rate Asrama BDK Balikpapan

\begin{tabular}{|l|l|l|l|}
\hline No & \multicolumn{1}{|c|}{ Tahun } & \multicolumn{1}{|c|}{$\begin{array}{c}\text { Kapasitas yang } \\
\text { digunakan }\end{array}$} & $\begin{array}{c}\text { Nonproductive } \\
\text { Capacity Rate }\end{array}$ \\
\hline 1 & 2017 & 1205 kamar setahun & $10,00 \%$ \\
\hline 2 & 2018 & 932 kamar setahun & $7,73 \%$ \\
\hline 3 & 2019 & 728 kamar setahun & $6,04 \%$ \\
\hline
\end{tabular}

Sumber: data diolah oleh penulis (2019)

Dapat dilihat terjadi penurunan nonproductive capacity rate yang penyebab utamanya adalah proses maintenance di tahun 2017 yang memakan waktu lama.

\subsection{Idle capacity}

Idle capacity merupakan kapasitas yang menganggur, baik yang disebabkan karena kebijakan/aturan internal maupun kondisi eksternal. Kapasitas menganggur dapat digunakan jika entitas mampu meningkatkan kegiatan operasionalnya, tetapi pada kenyataannya kapasitas tersebut tidak digunakan. Idle capacity dihitung dengan mengurangkan productive capacity dan nonproductive capacity dari rated capacity. Hasil perhitungan idle capacity asrama BDK Balikpapan sebagaimana pada Tabel 13.

\section{Tabel 13 Idle Capacity Rate Asrama BDK Balikpapan}

\begin{tabular}{|l|l|l|l|}
\hline No & \multicolumn{1}{|c|}{ Tahun } & \multicolumn{1}{c|}{$\begin{array}{c}\text { Kapasitas yang } \\
\text { digunakan }\end{array}$} & $\begin{array}{c}\text { Idle Capacity } \\
\text { Rate }\end{array}$ \\
\hline 1 & 2017 & 6787 kamar setahun & $56,34 \%$ \\
\hline 2 & 2018 & 5531 kamar setahun & $45,91 \%$ \\
\hline 3 & 2019 & 6253 kamar setahun & $56,31 \%$ \\
\hline
\end{tabular}

Sumber: data diolah oleh penulis (2019)

Mahmudi (2010:111) membagi tingkat efisiensi dalam manajemen kinerja sektor publik menjadi sangat efisien, efisien, cukup efisien, dan kurang efisien. Berdasarkan pembagian tersebut, tingkat idle capacity penggunaan asrama BDK Balikpapan termasuk tinggi dan kurang efisien. Peneliti tidak mendapatkan data yang cukup untuk menyimpulkan tingkat idle capacity rate BMN BDK Balikpapan. Namun, berdasarkan Fadjarwati (2014), idle capacity BDK Balikpapan masih lebih rendah dibandingkan pada Balai Pelatihan dan Kesehatan Dinas Kesehatan Jawa Barat, yaitu sebesar 58,08\% pada tahun 2012 .

Berdasarkan data pada Tabel 13, rerata idle capacity rate asrama BDK Balikpapan tahun 20172019 adalah 52,85\%. Idle capacity rate tahun 2017 merupakan yang tertinggi, yaitu sebesar 56,34\%. Hal ini berbanding terbalik dengan jumlah pelatihan pada tahun 2017 yang lebih banyak dibanding tahun 2018 
dan 2019. Hasil wawancara dan data kalender pembelajaran menunjukkan bahwa 11 dari 32 pelatihan yang diselenggarakan tahun 2017 menggunakan asrama eksternal. Pada tahun 2018 terjadi penurunan idle capacity rate penggunaan asrama. Data tersebut sebanding dengan productive capacity tertinggi di tahun 2018 dibanding tahun 2017 dan 2019. Berdasarkan hasil tersebut, diketahui bahwa terjadi peningkatan optimalisasi BMN. Namun, upaya lebih lanjut masih dapat dilakukan untuk memanfaatkan idle capacity rated sebesar lebih dari $45 \%$ tersebut. Idle capacity rated tahun 2019 meningkat dibanding tahun 2018 seiring dengan berkurangnya jumlah pelatihan di tahun tersebut. Dengan membandingkan data proyeksi pelatihan tahun 2020, diperkirakan idle capacity rated juga akan meningkat. Idle capacity asrama BDK Balikpapan dipengaruhi penurunan jumlah pelatihan yang diselenggarakan. Penurunan jumlah pelatihan tatap muka sejalan dengan peningkatan pelatihan $e$ learning. Hal ini menunjukkan bahwa implementasi pelatihan e-learning berdampak pada peningkatan idle capacity rated asrama BDK Balikpapan, sehingga ada ruang bagi BDK Balikpapan untuk mengoptimalkan penggunaan asetnya.

Idle capacity atau kapasitas menganggur terdiri dari idle marketable, idle not marketable, dan idle off limits. Idle off limits merupakan kondisi di mana kapasitas tidak tersedia karena libur, kontrak, atau kebijakan atau strategi dari pihak manajemen. Wawancara menunjukkan bahwa yang kebijakan penggunaan kamar 501 merupakan idle off limits pada BDK Balikpapan. Setelah dilakukan pekerjaan konstruksi renovasi asrama dan pembuatan tempat parkir BDK Balikpapan Tahun 2017, kamar 501 diperuntukkan khusus bagi tamu tertentu, seperti pengajar atau pejabat. Hal ini, salah satunya, karena pertimbangan efisiensi biaya penginapan tamu (dibandingkan menggunakan hotel). Namun, kebijakan tersebut membatasi penggunaan kamar 501. CAM-I Capacity Model menilai kebijakan tersebut menyebabkan idle off limits pada penggunaan kamar 501. Peneliti tidak mendapatkan data penggunaan kamar 501 baik di tahun 2018 maupun 2019, sehingga peneliti mengategorikan keseluruhan kapasitas kamar 501 sebagai idle off limits. Dengan demikian, idle off limits tahun 2018 dan 2019 adalah 365.

Tabel 14: PNBP Penyewaan BMN BDK Balikpapan

\begin{tabular}{|l|c|c|}
\hline No & Tahun & PNBP Penyewaan BMN \\
\hline 1 & 2017 & Rp9.763.000 \\
\hline 2 & 2018 & Rp9.409.000 \\
\hline 3 & 2019 & Rp9.534.000 \\
\hline
\end{tabular}

Sumber: data diolah oleh penulis (2019)

Menurut Siregar (2004), optimasi pengelolaan aset perlu memaksimalkan ketersediaan aset (maximize asset availability), memaksimalkan penggunaan aset (maximize asset utilization), dan meminimalkan biaya kepemilikan (minimize cost of ownership). Berdasarkan analisis idle capacity, optimalisasi yang dapat dilakukan BDK Balikpapan adalah dengan memaksimalan penggunaan aset. Idle capacity sebesar 40-50\% tersebut dapat dioptimalkan untuk meningkatkan output penyelenggaraan pelatihan di BDK Balikpapan. Data tersebut menunjukkan bahwa BDK Balikpapan dapat menyelenggarakan pelatihan dengan jumlah yang lebih banyak. Pusdiklat dapat mempertimbangkan data idle capacity dalam menugaskan penyelenggaraan pelatihan pada BDK Balikpapan. Selain itu, BDK Balikpapan dapat memanfaatkan idle capacity yang ada sebagai sumber PNBP. Tabel 14 menunjukkan PNBP BDK Balikpapan atas pemanfaatan BMN. Idle capacity yang ada merupakan potensi yang dapat dimanfaatkan untuk meningkatkan PNBP. Namun, untuk mengidentifikasi idle capacity asrama BDK Balikpapan sebagai idle marketable atau idle notmarketable memerlukan kajian lebih lanjut. Tulisan ini hanya ditujukan untuk menghitung idle capacity penggunaan asrama BDK Balikpapan.

\section{KESIMPULAN}

Berdasarkan analisis perhitungan idle capacity penggunaan asrama BDK Balikpapan dengan menggunakan CAM-I Capacity Model, sebagai berikut.

a. Productive capacity asrama BDK Balikpapan tahun 2017-2019 secara berurutan adalah 33,65\%, 46,34\%, dan 42,04\%. Rerata productive capacity selama rentang waktu tersebut adalah 40,67\%.

b. Nonproductive capacity asrama BDK Balikpapan tahun 2017-2019 secara berurutan adalah 10,00\%, 7,73\%, dan 6,04\%. Rerata nonproductive capacity selama rentang waktu tersebut adalah 7,92\%.

c. Idle capacity asrama BDK Balikpapan tahun 20172019 secara berurutan adalah 56,34\%, 45,91\%, dan $56,31 \%$. Rerata idle capacity selama rentang waktu tersebut adalah 52,85\%.

Hasil perhitungan tersebut menunjukkan bahwa productive capacity asrama BDK Balikpapan dari tahun 2017-2019 lebih rendah dibandingkan idle capacity, baik secara tahunan maupun secara rerata dalam rentang waktu tersebut. Dengan kata lain asrama BDK Balikpapan selama rentang waktu tersebut lebih banyak dalam kondisi tidak digunakan atau idle.

\section{IMPLIKASI DAN KETERBATASAN}

Pemanfaatan idle capacity merupakan potensi bagi BPPK sebagai Kemenkeu Corporate University untuk meningkatkan kualitas layanannya. Data idle capacity menunjukkan bahwa peningkatan kuantitas pelatihan e-learning dapat dilakukan tanpa mengurangi kuantitas pelatihan tatap muka sehingga cakupan BPPK dalam menyelenggarakan pelatihan bagi pegawai Kementerian Keuangan menjadi lebih besar. BPPK dapat menerapkan metode CAM-I 
Capacity Model di seluruh unit kerjanya untuk menghitung idle capacity BMN, untuk menunjang pengambilan keputusan dalam mengelola aset. Selain itu, pemanfaatan idle capacity sebagai sumber PNBP perlu dikaji lebih lanjut, terutama untuk menentukan apakah idle capacity tersebut termasuk marketable atau nonmarketable.

Dalam penelitian ini, perhitungan dilakukan dengan menggunakan theoretical capacity, perhitungan menjadi lebih akurat jika terdapat data practical capacity yang dapat diperoleh melalui optimalisasi RMS pada menu peminjaman ruangan aplikasi Semantik yang selama ini hanya mengakomodasi peminjaman ruangan.

\section{DAFTAR PUSTAKA}

Sumber Buku

Siregar, D. D. (2004). Manajemen Aset. PT Gramedia Pustaka Utama.

Jurnal

Aditya, M. (2014). Perhitungan Idle capacity dengan menggunakan CAM-I Capacity Model dalam Rangka Efisiensi Biaya pada PT X. Jurnal Bisnis dan Manajemen.

Fadjarwati, N., \& Koswara, N. 2014. Optimalisasi Pemanfaatan Aset Gedung Balai Pelatihan Kesehatan Dinas Kesehatan Provinsi Jawa

BPPK. (2016). BPPK Dalam Angka 2010-2015 (Perspetif Keuangan). BPPK.

Keputusan Kepala Badan Pendidikan dan Pelatihan Keuangan Nomor KEP-140/PP/2017 tentang Cetak Biru Kementerian Keuangan Corporate University

Laporan Keuangan Pemerintah Pusat Tahun 2015

Laporan Keuangan Pemerintah Pusat Tahun 2016

Laporan Keuangan Pemerintah Pusat Tahun 2017
Barat melalui Strategi Pemasaran. Jurnal Orasi Bisnis Edisi ke-XI, Mei 2014.

Huefner, R. J. (2011). A Guide to Integrating Revenue Management and Capacity Analisys. Management Accounting Quaterly.

Institute of Management Accountants (IMA). (1996). Measuring The Cost of Capacity. Institute of Management Accountants (IMA)

Irwanti, D. (2014). Analisis Biaya Kapasitas di Instansi Pemerintah dengan Menggunakan Time Driven Activity Based Costing (Studi Kasus KPP Madya Malang). Sekolah Tinggi Akuntansi Negara.

Jusmin. (2013). Pengaruh Manajemen Aset Terhadap Tingkat Optimalisasi Aset Tetap (Tanah dan Bangunan) Pemerintah Kota Baubau. Tesis FEB UGM.

Mahmudi. (2010). Manajemen Kinerja Sektor Publik. UPP STIM YKPN.

Preda, P., \& Watts, T. (2003). Improving the Efficiency of Sporting Venues Through Capacity Management: The Case of The Sydney (Australia). Cricket Ground Trust.

Sopariwala, P. R. (2006). Capacity Model in a MultiHierarchical Manufacturing Environtment. Management Accounting Quarterly.

Naskah Produk Kebijakan

Laporan Keuangan Pemerintah Pusat Tahun 2018

Notula Rapat Koordinasi BPPK Tahun 2018

Pendapat BPK 2015

Peraturan Menteri Keuangan Nomor 71/PMK.06/2016 tentang Tata Cara Pengelolaan Barang Milik Negara yang Tidak Digunakan untuk Menyelenggarakan Tugas dan Fungsi Kementerian Negara/Lembaga 
PERHITUNGAN IDLE CAPACITY DENGAN MENGGUNAKAN CAM-I CAPACITY MODEL :

\section{LAMPIRAN}

Kalender Pembelajaran BDK Balikpapan Tahun 2017

\begin{tabular}{|c|c|c|c|c|c|c|c|c|c|}
\hline No & NAMA DIKLAT & SEMANTIK & JAMLAT & $\begin{array}{l}\text { LAMA } \\
\text { (DIKLAT) }\end{array}$ & $\begin{array}{l}\text { LAMA } \\
\text { (ASRAMA) }\end{array}$ & $\begin{array}{l}\text { RENCANA } \\
\text { PESERTA }\end{array}$ & REALISASI & WAKTU PENYELENGGARAAN & КET. \\
\hline 1 & \begin{tabular}{|l} 
Diklat Penyiapan Tenaga Pendamping Penyusunan LKKL \\
Angkatan I (Program Pusdiklat AP)
\end{tabular} & & 28 & 3 & 5 & 29 & 29 & 11.s.d. 13 Januari 2017 & Asrama BDK \\
\hline 2 & DTSS Penyuluhan Perpajakan & DTSS Penyuluhan Perpajakan (tidak asrama) & 57 & 5 & 7 & 35 & 34 & 16 s.d. 20 Januari 2017 & Asrama BDK \\
\hline 3 & Diklat Persiapan Purnabhakti Akt I & Diklat Persiapan Purnabhakti Akt I & 44 & 5 & 7 & 27 & 25 & 16 s.d. 20 Januari 2017 & Asrama BDK \\
\hline 4 & DTSS Petugas Tempat Pelayanan Terpadu & DTSS Petugas Tempat Pelayanan Terpadu & 49 & 5 & 7 & 28 & 28 & 30 Jan s.d. 3 Feb 2017 & Asrama BDK \\
\hline 5 & DTSS Operator Console Perpajakan & DTSS Operator Console Perpajakan & 50 & 5 & 7 & 31 & 31 & 30 Jan s.d. 3 Feb 2017 & Asrama BDK \\
\hline 6 & Lokakarya Penggalian Potensi Perpajakan & Lokakarya Penggalian Potensi Perpajakan & 29 & 3 & 4 & 28 & 28 & 6 s.d. 8 Feb 2017 & Asrama BDK \\
\hline 7 & Diklat Bendahara Pengeluaran APBN & Diklat Bendahara Pengeluaran APBN & 42 & 5 & 7 & 30 & 29 & 6 s.d. 10 Feb 2017 & Asrama BDK \\
\hline 8 & Diklat Persiapan Purnabhakti Akt II & Diklat Persiapan Purnabhakti Akt II & 44 & 5 & 7 & 27 & 18 & 13 s.d. 17 Februari 2017 & Asrama BDK \\
\hline 9 & DTSS Juru Sita Pajak & DTSS Juru Sita Pajak & 75 & 9 & 13 & 20 & 20 & 20 Feb s.d. 2 Mar 2017 & Asrama BDK \\
\hline 10 & Diklat Pengadaan Barang/Jasa Pemerintah & Diklat Pengadaan Barang/Jasa Pemerintah & 40 & 5 & 7 & 24 & 26 & 27 Feb s.d. 3 Maret 2017 & Asrama BDK \\
\hline 11 & $\begin{array}{l}\text { Lokakarya Pengambilan Contoh dan Pengukuran Jumlah } \\
\text { Komoditi Mineral serta Kelapa Sawit, CPO, dan Produk } \\
\text { Turunannya }\end{array}$ & $\begin{array}{l}\text { Lokakarya Pengambilan Contoh dan Pengukuran Jumlah } \\
\text { Komoditi Mineral serta Kelapa Sawit, CPO, dan Produk } \\
\text { Turunannya }\end{array}$ & 48 & 5 & 7 & 30 & 29 & 13 s.d. 17 Maret 2017 & Asrama BDK \\
\hline 12 & $\begin{array}{l}\text { Lokakarya Perangkat Pengadaan Barang/Jasa Bagi Pegawai } \\
\text { DJPB (Pusdiklat AP) }\end{array}$ & & 22 & 2 & 4 & 20 & 20 & 11 s.d. 12 Maret 2017 & Asrama BDK \\
\hline 13 & $\begin{array}{l}\text { Lokakarya Penyaluran Dana alokasi Khusus Fisik (DAK) dan } \\
\text { Dana Desa }\end{array}$ & $\begin{array}{l}\text { Lokakarya Penyaluran Dana alokasi Khusus Fisik (DAK) dan } \\
\text { Dana Desa }\end{array}$ & 33 & 3 & 5 & 44 & 44 & 20 s.d. 22 Maret 2017 & Asrama BDK \\
\hline$\frac{14}{15}$ & $\begin{array}{l}\text { Workshop Coaching Bagi Pejabat DJPB Angkatan I } \\
\text { Workshop Coaching Bagi Pejabat DJPB Angkatan II }\end{array}$ & $\begin{array}{l}\text { Workshop Coaching Bagi Pejabat DJPB Angkatan I } \\
\text { Workshop Coaching Bagi Pejabat DJPB Angkatan II } \\
\end{array}$ & $\frac{13}{13}$ & $\frac{2}{2}$ & $\begin{array}{ll}3 \\
3\end{array}$ & $\frac{19}{16}$ & $\frac{18}{16}$ & $\begin{array}{l}\text { 23 s.d. } 24 \text { Maret } 2017 \\
\text { 3 s.d. } 4 \text { April } 2017\end{array}$ & $\begin{array}{l}\text { Asrama BDK } \\
\text { Asrama BDK }\end{array}$ \\
\hline 16 & DTSS Pemeriksaan Barang Penumpang & DTSS Pemeriksaan Barang Penumpang & 68 & 7 & 9 & 30 & 30 & 2 s.d. 9 Mei 2017 & Asrama BDK \\
\hline 17 & Pelatihan Dasar CPNS Golongan II Periode I & Pelatihan Dasar CPNS Golongan II Periode I & 288 & 33 & 43 & 33 & 33 & $\begin{array}{l}2 \text { Mei s.d. } 7 \text { Juni (18 s.d. } 20 \text { Sept } \\
\text { Evaluasi) }\end{array}$ & Asrama BDK \\
\hline 18 & Diklat AKSI UKI Kelas Reguler & Diklat AKSI UKI Kelas Reguler & 48 & 5 & 7 & 25 & 25 & 15 s.d. 19 Mei 2017 & Asrama Eksternal \\
\hline 19 & $\begin{array}{l}\text { Lokakarya Pemeriksaan Industri Kelapa Sawit dan } \\
\text { Perusahaan Grup }\end{array}$ & & 28 & 3 & 5 & 41 & 41 & 15 s.d. 17 Mei 2017 & Asrama Eksternal \\
\hline 20 & \begin{tabular}{|l} 
Lokakarya Modus Operandi, Industri Rumah Sakit, Farmasi, \\
Dan Perusahaan Besar Farmasi
\end{tabular} & & 28 & 3 & 5 & 36 & 36 & 22 s.d. 24 Mei 2017 & Asrama Eksternal \\
\hline 21 & $\begin{array}{l}\text { Diklat Penyiapan Tenaga Pendamping Penyusunan LKKL } \\
\text { Angkatan II (Program Pusdiklat AP) }\end{array}$ & & 28 & 3 & 5 & 32 & 32 & 22 s.d. 24 Mei 2017 & Asrama Eksternal \\
\hline 22 & Pelatihan Dasar CPNS Golongan II Periode II & & 288 & 33 & 36 & 33 & 33 & $\begin{array}{c}10 \text { Juli s.d. } 8 \text { Agustus } 2017 \text { (13 s.d. } \\
15 \text { Nov } 2017 \text { Evaluasi) }\end{array}$ & Asrama BDK \\
\hline 23 & Diklat Manajemen SDM Tingkat Dasar & Diklat Manajemen SDM Tingkat Dasar & 42 & 5 & 6 & 13 & 13 & 17 s.d. 21 Juli 2017 & Asrama Eksternal \\
\hline 24 & Diklat Analisis Lap. Keuangan Tingkat Dasar & Diklat Analisis Lap. Keuangan Tingkat Dasar & 47 & 5 & 6 & 30 & 30 & 31 Juli s.d. 4 Agustus 2017 & Asrama Eksternal \\
\hline 25 & Diklat Kearsipann & Diklat Kearsipann & 48 & 5 & 6 & 27 & 27 & 7 s.d. 11 Agustus 2017 & Asrama Eksternal \\
\hline 26 & Pelatihan Dasar CPNS Golongan II Periode III & Pelatihan Dasar CPNS Golongan II Periode III & 288 & 33 & 36 & 34 & 34 & \begin{tabular}{|c|}
9 Agst s.d. 9 Sept 2017 ( 20 s.d. 22 \\
Des 2017 Evaluasi)
\end{tabular} & Asrama BDK \\
\hline 27 & Seminar Soft Skill Bagi Pegawai DJPB Kaltim & & 5 & 1 & & 90 & 90 & 16 Agustus 2017 & Tidak Asrama \\
\hline 28 & Diklat Manajemen Risiko Kelas Reguler & Diklat Manajemen Risiko Kelas Reguler & 45 & 5 & 6 & 25 & 25 & 21 s.d. 23 Agustus 2017 & Asrama Eksternal \\
\hline 29 & $\begin{array}{l}\text { Lokakarya Pemeriksaan Industri Kelapa Sawit dan } \\
\text { Perusahaan Grup }\end{array}$ & & 28 & 3 & 4 & 92 & 92 & 23 s.d. 25 Agustus 2017 & Tidak Asrama \\
\hline 30 & Diklat Microsoft Acces Tingkat Dasar & Diklat Microsoft Acces Tingkat Dasar & 48 & 5 & 6 & 32 & 32 & 4 s.d. 8 September 2017 & Asrama Eksternal \\
\hline 31 & Diklat Pengelolaan Kinerja & Diklat Pengelolaan Kinerja & 47 & 5 & 6 & 31 & 31 & 11 S.D. 15 September 2017 & Asrama Eksternal \\
\hline 32 & Diklat Peningkatan Kompetensi Excellent Front Liners & Diklat Peningkatan Kompetensi Excellent Front Liners & 37 & 5 & 6 & 30 & 30 & 11 s.d. 15 September 2017 & Asrama Eksternal \\
\hline 33 & Diklat Manajemen Risiko Kelas Manajerial & Diklat Manajemen Risiko Kelas Manajerial & 31 & 3 & 5 & 19 & 18 & 18 s.d. 19 September 2017 & Asrama BDK \\
\hline 34 & Diklat Tata Naskah Dinas (TND) & Diklat Tata Naskah Dinas (TND) & 44 & 5 & 7 & 23 & 23 & 25 s.d. 29 September 2017 & Asrama BDK \\
\hline 35 & DTSS Pemeriksaan Barang Ekspor & DTSS Pemeriksaan Barang Ekspor & 102 & 12 & 19 & 30 & 30 & 2 s.d. 18 Oktober 2017 & Asrama BDK \\
\hline
\end{tabular}


Kalender Pembelajaran BDK Balikpapan Tahun 2018

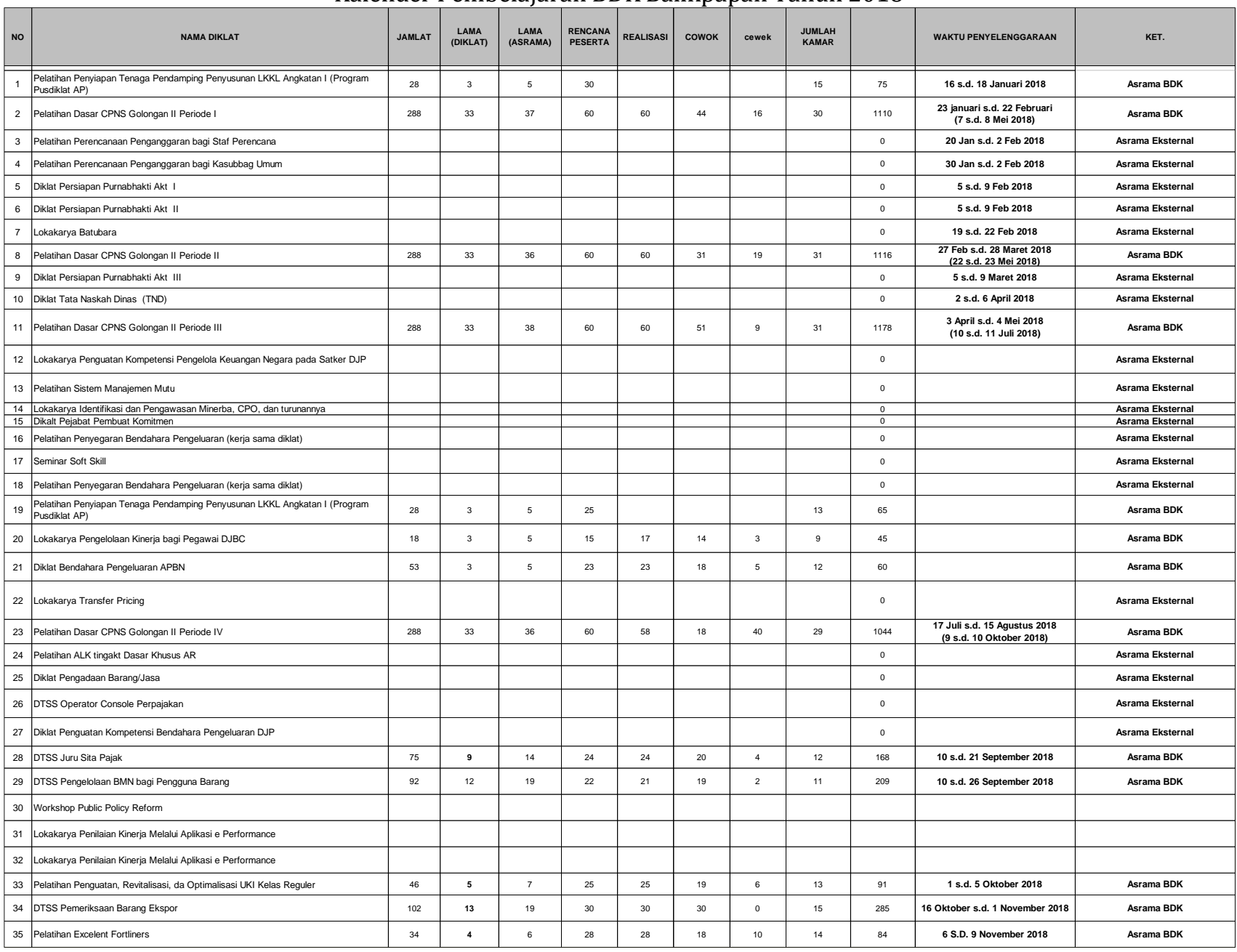

Kalender Pembelajaran BDK Balikpapan Tahun 2019

\begin{tabular}{|c|c|c|c|c|c|c|c|c|c|c|c|c|c|}
\hline мо & NAMA DIKLAT & Mulai & Selesai & JAMLAT & $\begin{array}{l}\text { LAMA } \\
\text { (DIKLAT) }\end{array}$ & $\underset{\text { (LASRAMA) }}{\operatorname{LamA}}$ & $\begin{array}{l}\text { RENCANA } \\
\text { PESERTA }\end{array}$ & REALISASI & сошок & cewek & $\begin{array}{l}\text { JUMLAH } \\
\text { KAMAR }\end{array}$ & & КЕт. \\
\hline 1 & Pelatithan Tata Naskah Dinas Angkatan I & $18 \operatorname{Jan} 19$ & 01 Feb 19 & 35 & ${ }^{4}$ & 6 & ${ }_{30}$ & 22 & 11 & 11 & 12 & 72 & Asrama BDK \\
\hline 2 & Pelatihan Tata Naskah Dinas Angkatan II & $24 \operatorname{Jan} 19$ & 08 Feb 19 & 35 & 4 & 6 & sо & ${ }_{30}$ & 15 & 15 & 16 & 96 & Asrama BDK \\
\hline 3 & Pelatithan Bendahara Pengeluaran APBN Angkatan I & $30 \operatorname{Jan} 19$ & 15 Feb 19 & 51 & 5 & 7 & 25 & 26 & 11 & 15 & 14 & 98 & Asrama BDK \\
\hline 4 & Pelatihan Pengadaan Barang//asa Pemerintah Angkatan I & 08 Feb 19 & 22 Feb 19 & 60 & 5 & 7 & ${ }_{30}$ & 32 & 28 & 4 & 16 & 112 & Asrama BDK \\
\hline 5 & Pelatitian Pengelolaan Kinerja & 11 Feb 19 & 15 Feb 19 & ${ }_{42}$ & 5 & 7 & 27 & 28 & 18 & 10 & 14 & 98 & Asrama BDK \\
\hline 6 & Pelatihan Dasar CPNS Golongan II (Blended Learning) Periode I| & 18 Feb 19 & 17 May 19 & 555 & 22 & 34 & 60 & 59 & 25 & 34 & 30 & 1020 & Asrama BDK \\
\hline 7 & Pelatihan Penguatan Kompetensi Teknis Bidang Tugas CPNS Golongan || (e-Learning) Periode || & $18 \mathrm{Feb} 19$ & 02 Apr 19 & ${ }_{40}$ & 24 & & 60 & 60 & & & & 0 & e-learning \\
\hline 8 & Pelatitian Teknis Operator Console Pajak & 18 Feb 19 & 22 Feb 19 & 51 & 5 & 7 & 22 & 22 & 16 & 6 & 11 & 77 & Asrama BDK \\
\hline 9 & Pelatihan Peningkatan Kompetensi Eselon IV & 25 Feb 19 & 01 Mar 19 & ${ }_{42}$ & 5 & 7 & 22 & ${ }_{19}$ & 19 & 0 & 10 & 70 & Asrama BDK \\
\hline 10 & Lokakarya Pengelolaan Uang Persediaan Bagi Bendahara di Lingkungan Direktorat Jenderal Pajak Angkatan I & 05 Mar 19 & 06 Mar 19 & 20 & 2 & 4 & ${ }_{42}$ & ${ }_{42}$ & & & & 0 & Tidak Asrama \\
\hline 11 & Pelatihan Dasar CPNS Golongan II (Blended Learning) Periode III & 16 Mar 19 & 27 Jun 19 & 555 & ${ }_{22}$ & 32 & 60 & 60 & 35 & 25 & 31 & 992 & Asrama BDK \\
\hline 12 & Pelatihan Penguatan Kompetensi Teknis Bidang Tugas CPNS Golongan II (e-Learning) Periode III & 16 Mar 19 & 03 May 19 & ${ }_{40}$ & 24 & & 60 & 60 & & & & 0 & e-learning \\
\hline 13 & Pelatihan Dasar CPNS Golongan III (Blended Learning) Periode IV & 08 Jun 19 & $06 \operatorname{Sep} 19$ & 555 & 22 & 32 & 60 & 59 & 32 & 27 & ${ }_{30}$ & 960 & Asrama BDK \\
\hline$\frac{14}{14}$ & Pelatihan Teknis Orientasi untuk Pegawai Pajak Angkatan I & 26 Jun 19 & 05 Jul 19 & $\frac{115}{555}$ & $\frac{10}{22}$ & 32 & $\frac{37}{60}$ & $\frac{37}{60}$ & 20 & 4 & 30 & 0 & Asrama Eksternal \\
\hline 16 & \begin{tabular}{|l|} 
Pelatitahn Dasar r PNS Golongan III(Blended learning) Periode V \\
Pelatihan Teknis Pajak Dasar AAgkatan I
\end{tabular} & 08 Jul 19 & 16 Aug 19 & 273 & 30 & & 37 & 37 & & & & 960 & $\begin{array}{l}\text { Asrama BDK } \\
\text { Tidak Asrama }\end{array}$ \\
\hline 17 & Pelatihan Teknis orientasi untuk Pegawai Pajak Angkatan ॥ & 17 Jul 19 & 26 Jul 19 & 115 & ${ }_{10}$ & & ${ }_{37}$ & ${ }_{37}$ & & & & 0 & Asrama Eksternal \\
\hline 18 & Pelatihan Teknis Pajak Dasar Angkatan II & 29 Jul 19 & $06 \operatorname{Sep} 19$ & 274 & 30 & & 37 & 37 & & & & 0 & Tidak Asrama \\
\hline 19 & Pelatihan Teknis orientasi untuk Pegawai Pajak Angkatan III & 07 Aug 19 & 16 Aug 19 & 115 & ${ }_{10}$ & & ${ }_{37}$ & 37 & & & & 0 & Asrama Eksternal \\
\hline 20 & Pelatihan Teknis Pajak Dasar Angkatan III & 19 Aug 19 & $27 \operatorname{sep} 19$ & 274 & ${ }_{30}$ & & ${ }_{37}$ & ${ }_{37}$ & 14 & 3 & & 0 & Tidak Asrama \\
\hline 21 & Pelatihan Peniliain SDA berupa Hutan Konservasi & 26 Aug 19 & 30 Aug 19 & 52 & 5 & 7 & 20 & 16 & 17 & 1 & 9 & 63 & Asrama BDK \\
\hline 22 & Pelatihan Teknis orientasi untuk Pegawai Pajak Angkatan IV & 28 Aug 19 & 06 Sep 19 & 115 & ${ }_{10}^{10}$ & & 36 & 36 & & & & 0 & Asrama Eksternal \\
\hline 23 & Pelatihan Teknis Pajak Dasar Angkatan IV & 09 Sep 19 & 18 oct 19 & 274 & 30 & & 33 & ${ }_{33}$ & 18 & 40 & & 0 & Tidak Asrama \\
\hline 24 & Pelatihan Teknis Pemeriksaan Barang Ekspor & 07 oct 19 & 23 oct 19 & ${ }_{110}$ & ${ }_{13}$ & 19 & 30 & 30 & 30 & 0 & 15 & 285 & Asrama BDK \\
\hline
\end{tabular}

